\title{
Integrated approach for identification of potential groundwater zones in Seethanagaram Mandal of Vizianagaram District, Andhra Pradesh, India
}

\author{
N C MONDAL ${ }^{1, *}, \mathrm{~S}$ N DAS ${ }^{2}$ and V S Singh ${ }^{1}$ \\ ${ }^{1}$ National Geophysical Research Institute, Hyderabad 500 00\%, India. \\ ${ }^{2}$ Action for Food Production (AFPRO), Hyderabad 500 00\%, India. \\ *e-mail: ncmngri@yahoo.co.in
}

Identifying a good site for groundwater exploration in hard rock terrain is a challenging task. In hard rocks, groundwater occurs in secondary porosity developed due to weathering, fracturing, faulting, etc., which is highly variable within short distance and contributing to near-surface inhomogeneity. In such situations topographic, hydrogeological and geomorphological features provide useful clues for the selection of suitable sites.

Initially, based on satellite imagery, topographical, geomorphological and hydrogeological features, an area of about $149 \mathrm{~km}^{2}$ was demarcated as a promising zone for groundwater exploration in the hard rock tract of Seethanagaram Mandal, Vizianagaram District, Andhra Pradesh, India. A total of 50 Vertical Electrical Soundings (VES) were carried out using Wenner electrode configuration. An interactive interpretation of the VES data sharpened the information inferred from geomorphological and hydrogeological reconnaissance. Ten sites were recommended for drilling. Drilling with Down-The-Hole Hammer (DTH) was carried out at the recommended sites down to 50 to $70 \mathrm{~m}$ depths. The interpreted VES results matched well with the drilled bore well lithologs. The yields of bore wells vary from 900 to 9000 liters per hour (lph).

\section{Introduction}

There are several difficulties in developing groundwater resources in hard rock areas. Wide and erratic variations of aquifer parameters characterize the groundwater regime. Spatial variation of these characteristic parameters attribute to, among other causes, tectonic set-up and degree of weathering of near-surface rocks (Barker et al 2001). These processes induce directly or indirectly secondary porosity in the hard rocks to a variable extent. As a result, the groundwater potential also varies significantly from place to place, sometimes within few meters and even within the same geological formations. In the Indian context, the situation becomes more precarious due to negligible primary porosity and low permeability of host rocks restricting groundwater storage as well as movement. Further, low rainfall, high evaporation and run-off limit recharge to the groundwater systems (Rangarajan and Athavale 2000). However, experience in hard rock terrain, granite areas in particular, has shown that a systematic surface exploration succeeds in locating sites for high yielding wells.

Seethanagaram Mandal in Vizianagaram district of Andhra Pradesh lies in hard rock terrain. Groundwater is available only in weathered and fractured zones. In this area assured surface water supplies are nominal and most of the farmers depend on groundwater for drinking and irrigation purposes. Average annual rainfall is around $1158.9 \mathrm{~mm}$ which is mostly lost as surface runoff and evaporation. Only one-fifth of it is recharging to groundwater. Therefore,

Keywords. Groundwater; hard rock; Vertical Electrical Soundings; Down-The-Hole Hammer; pumping test; Seethanagaram Mandal. 


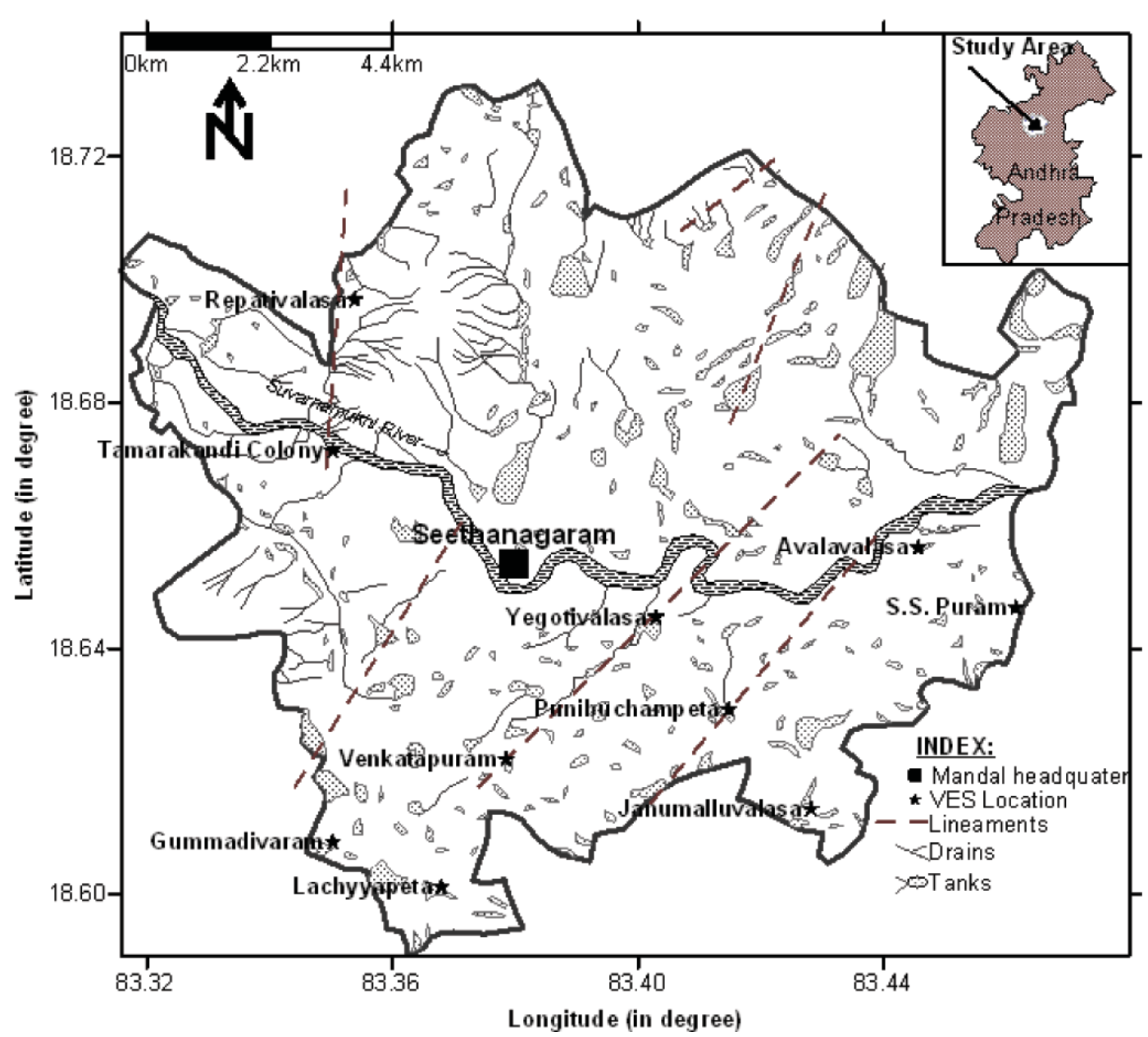

Figure 1. Location map of Seethanagaram Mandal, Andhra Pradesh.

groundwater development assumes great significance in improving the quality of life of the most deprived and vulnerable people of this mandal by improving their access to safe drinking water. Attempts were made to gather maximum information about the subsurface hydrogeological signatures favourable for groundwater occurrence using an appropriate mix of different techniques viz., satellite imagery, hydrogeological reconnaissance and geophysical exploration, etc. A conscious integration of the data helped to focus on the targeted zones and locate prospective drilling sites.

\section{Background of the area}

Seethanagaram Mandal is situated in the northern part of Vizianagaram district. The study area lies between latitudes: $18^{\circ} 35^{\prime} 23^{\prime \prime}$ and $18^{\circ} 43^{\prime} 56^{\prime \prime} \mathrm{N}$, and longitudes: $83^{\circ} 18^{\prime} 56^{\prime \prime}$ and $83^{\circ} 28^{\prime} 25^{\prime \prime} \mathrm{E}$, and spreads over an area of $149 \mathrm{~km}^{2}$ covering 44 villages, as shown in figure 1. It is bounded on the east by Srikakulam district, on the south by Suvarnamukhi river, Bobbili and Balijipeta mandals, on the west by Makkuva Mandal, and on the north by Parvathipuram and Garugubilli mandals. The type of drainage is subdendritic to dendritic. This mandal is mostly covered by red loamy, sandy loamy and silty clay soils with the thickness varying from 0.50 to $4.00 \mathrm{~m}$ (SGWD 2005). The chief crops grown in the mandal are paddy, ragi, green-gram, blackgram, sugarcane, sesamum and mesta. The area receives an average annual rainfall of $1158.9 \mathrm{~mm}$. The population density of the area is 370 person per sq. $\mathrm{km}$. Due to scarcity of surface water, people are using groundwater through dug wells, dugcum-bore wells, bore wells and infiltration wells for irrigation and drinking purposes.

\section{Methodology}

The satellite imageries (1:50,000 scales, collected from NRSA) were visually interpreted to delineate various hydro-geomorphological units based on structural trends, lineaments, and drainage and topographic features. The water-level fluctuations in the existing dug and bore wells were observed 
through well inventory. These wells are in the Archaean group of rocks (i.e., khondalites, porphyroblastic gneissic granite, gneisses and intrusive quartz veins) and alluvium. A total of 50 vertical electrical soundings (VES) were conducted using Wenner electrode configuration. An interactive interpretation of the VES data sharpened the information obtained from geomorphological and hydrogeological studies. Then site-specific inferences were drawn for recommending locations of bore wells. The bore wells were drilled by DownThe-Hole-Hammer (DTH) and the step draw down tests were conducted in the bore wells to compute specific capacity of wells.

\section{Hydrogeomorphology features}

The satellite images were examined based on visual interpretation and the study area was divided into several geomorphological units such as flood plains, pediments, pediplains, residual and structural hills. The denuded landforms are the products of weathering and erosion caused by different exogenetic geomorphic agents. Pediments and pediplains are distributed all over the area. The interpretation of satellite images in the mandal shows undulating topography with scarped strike ridges. The residual hills are located in the northern and southeastern parts of the study area. The structural hills identified are found on the western side and eastern side of Repativalasa, and western side of Jaggunayudupeta village. These hills are gently sloping towards east. The trend of the structural hills varies from NNE to SSW. The run-off is high with negligible infiltration, making them poor aquifers (Raju et al 1989). Flood plains and alluvial plains are found along the Suvarnamukhi river.

\subsection{Lineaments}

Lineaments, the large-scale linear features which are surficial expressions of underlying structural features like faults or joints in hard rock areas, are considered as potential good water zones. Areas in the up gradient of dykes or other intrusions within the host rock often possess good water potential as the dyke/intrusive constitutes barrier to groundwater flow. Lineament has generally been used as an indicative tool for locating potential groundwater zones (Yin and Brook 1992; Mabee et al 1994; Sander et al 1997; Magowe and Carr 1999; Mabee et al 2002), but with the present scenario of over-exploitation of the aquifer, characterization of the lineament becomes essential to ensure the possibility of locating potential groundwater zones and managing over-exploited aquifers in hard rock areas. A number of mega- and micro-lineaments are identified from the satellite imagery and further checked by field studies, and demarcated on a 1:50,000-scale map of the study area. The three major lineament sets in NE-SW directions are parallel to each other towards southeastern side of the area (figure 1). The other two sets are on the northern side. The maximum lineament density is found on the southeastern side. The lineaments are of varying dimensions and orientations; trending NE-SW. The drainage pattern in general and tributaries in particular, are controlled by the geological structures in the area, as revealed by the perfect linearity of the second- and third-order streams.

\subsection{Hydrogeology}

Major parts of this mandal are underlain by the Archaean group of rocks, while few patches are occupied by recent alluvium along the Suvarnamukhi river and other hill streams. The Archaean group of rocks comprise khondalites, porphyroblastic gneissic granite, gneisses and intrusive quartz veins. The depth of the weathered zone varies from $7.00 \mathrm{~m}$ to $13.00 \mathrm{~m}$. Hydrogeological surveys carried out in the mandal reveal that ground water occurs under water table conditions in the weathered and fractured zones. The alluvium consists of sand, silt and clay with the thickness varying from $5.00 \mathrm{~m}$ to more than $15.00 \mathrm{~m}$. Groundwater in alluvium occurs under both water table and semi-confined conditions. The depth of dug wells vary from $8.00 \mathrm{~m}$ to $12.00 \mathrm{~m}$ below ground level (bgl). The depth of water level ranges from 2.00 to $10.30 \mathrm{~m} \mathrm{bgl}$. The yield of the dug well ranges from 16,000 to 30,000 litres per hour (lph) depending on the nature of geological formation. The depth of bore wells on average ranges from 40 to $80 \mathrm{~m}$ with a discharge of 4000 to 15,000 litres per hour (lph). The infiltration wells are also constructed near river beds by removing the sand bed up to a suitable depth and putting percolation cement rings. The main objective of constructing infiltration wells is for providing drinking water to villagers. These wells have a very high yield ranging from 15,000 to 30,000 lph depending on the rainfall.

\section{Geophysical survey}

Some empirical, analytical and numerical methods have been developed for determining resistivity characteristics of the various subsurface formations (Tagg 1934; Roman 1934; Moore 1945; Mooney and Wetzel 1956; Compagnie Generale de Geophysique 1963; Orellana and Mooney 1966; Van Dam 1967; 


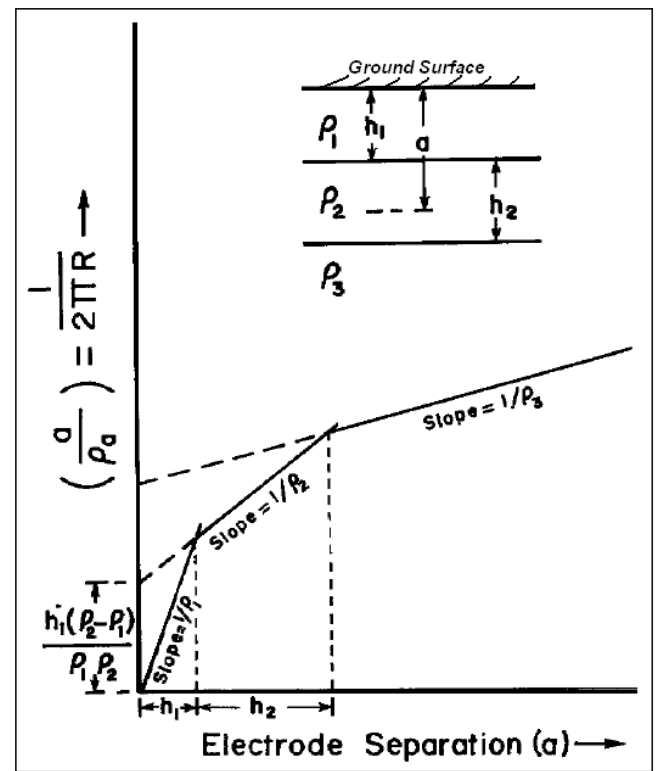

Figure 2. Plot of $1 / 2 \Pi R$ versus electrode separation based on Hummel's principle.

Ghosh 1971; Patra and Nath 1999). In the meantime Narayan and Ramanujachary (1967) showed that it is possible to solve the field equation directly to get resistivities and thicknesses of the subsurface layers from the field data by inverse slope method. It can be seen that the field data fall on discrete straight-line segments with sharp changes in slope in all the cases, representing the subsurface resistivity variations. The basic theory underlying this slope method is discussed here. If we begin by considering only a homogeneous medium of resistivity $\rho_{l}$, with an electrode separation ' $a$ ' in Wenner configuration then,

$$
\rho_{l}=2 \Pi a R,
$$

where $R$ is the actual measured resistance. Since it is a homogeneous layer, $\rho_{l}$ is constant for all values of ' $a$ ' and

$$
\frac{a}{\rho_{l}}=\frac{1}{2 \Pi R}
$$

If now a plot is made of $1 / 2 \Pi R$ against ' $a$ ' the graph will have a slope with the $a$-axis given by $l / \rho_{l}$, and will pass through the origin (figure 2).

Next, we consider a two-layer case of resistivity $\rho_{l}$ for the top layer and $\rho_{2}$ for the bottom layer and ' $h$ ' for depth to the discontinuity. It is assumed that the depth of sampling is equal to the electrode separation. The apparent resistivity for electrode separation ' $a$ ' will be equal to the average resistivity $\rho_{\text {ave }}$ of the material to a depth of ' $a$ '. Under these conditions, Hummel's principle (1931) states that

$$
\frac{h_{1}}{\rho_{l}}+\frac{\left(a-h_{1}\right)}{\rho_{2}}=\frac{a}{\rho_{\text {ave }}} .
$$

Rearranging terms gives

$$
\frac{h_{1}\left(\rho_{2}-\rho_{l}\right)}{\rho_{l} \rho_{2}}+\frac{a}{\rho_{2}}=\frac{a}{\rho_{\text {ave }}} .
$$

The first term on the left hand side is a constant. The graph of $a / \rho_{\text {ave }}(=1 / 2 \Pi R)$ versus ' $a$ ' will be a straight line with a slope $1 / \rho_{2}$ and an inter-

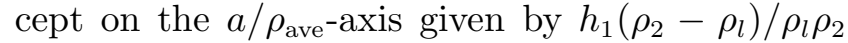
(figure 2). It will intersect the segment of slope $l / \rho_{1}$ (corresponding to the first layer) at a point whose abscissa will give the thickness $h_{1}$ of the first layer. If we consider a third layer of resistivity $\rho_{3}$ and thickness $h_{2}$, equation (2) now takes the form

$$
\frac{\left(h_{1}+h_{2}\right)\left(\rho_{3}-\rho_{\mathrm{ave} 1,2}\right)}{\left(\rho_{\mathrm{ave} 1,2}\right) \rho_{3}}+\frac{a}{\rho_{3}}=\frac{a}{\rho_{\mathrm{ave}}}
$$

where $\rho_{\mathrm{ave1}, 2}$ is the average resistivity of the first and second layers and $\rho_{\text {ave }}$ is now the average resistivity of all the three layers down to a depth ' $a$ '. On the graph this will be represented by another segment of slope $l / \rho_{3}$ and cutting the $a / \rho_{\text {ave-axis at }}$ an intercept $\left(h_{1}+h_{2}\right)\left(\rho_{3}-\rho_{\text {ave } 1,2}\right) /\left(\rho_{\text {ave1,2 }}\right) \rho_{3}$. The intersection of this segment with the previous one, projected down to the $a$-axis will give the quantity $\left(h_{1}+h_{2}\right)$ which is the depth to the second discontinuity (figure 2). This treatment can be extended to any number of layers.

In practice, one makes a plot of $1 / 2 \Pi R$, where $R$ is the measured resistance versus electrode separation ' $a$ '. On drawing the best fitting straight line segments through the points the intersections are read off for depths $h_{1}$, $\left(h_{1}+h_{2}\right), \ldots,\left(h_{1}+h_{2}+\cdots+h_{n}\right)$ with $n$ being any number of layers. The reciprocals of the corresponding slopes of the segments now give the absolute resistivities of the respective layers directly.

In Seethanagaram Mandal under Vizianagaram district of Andhra Pradesh, based on the geomorphological and hydrogeological studies, promising zones were demarcated for carrying out detailed vertical electrical soundings; and for gathering specific and reliable information about the occurrence and geometry of subsurface structures which may not have any surface signatures. VES method was used, and good resistivity contrast was measured 

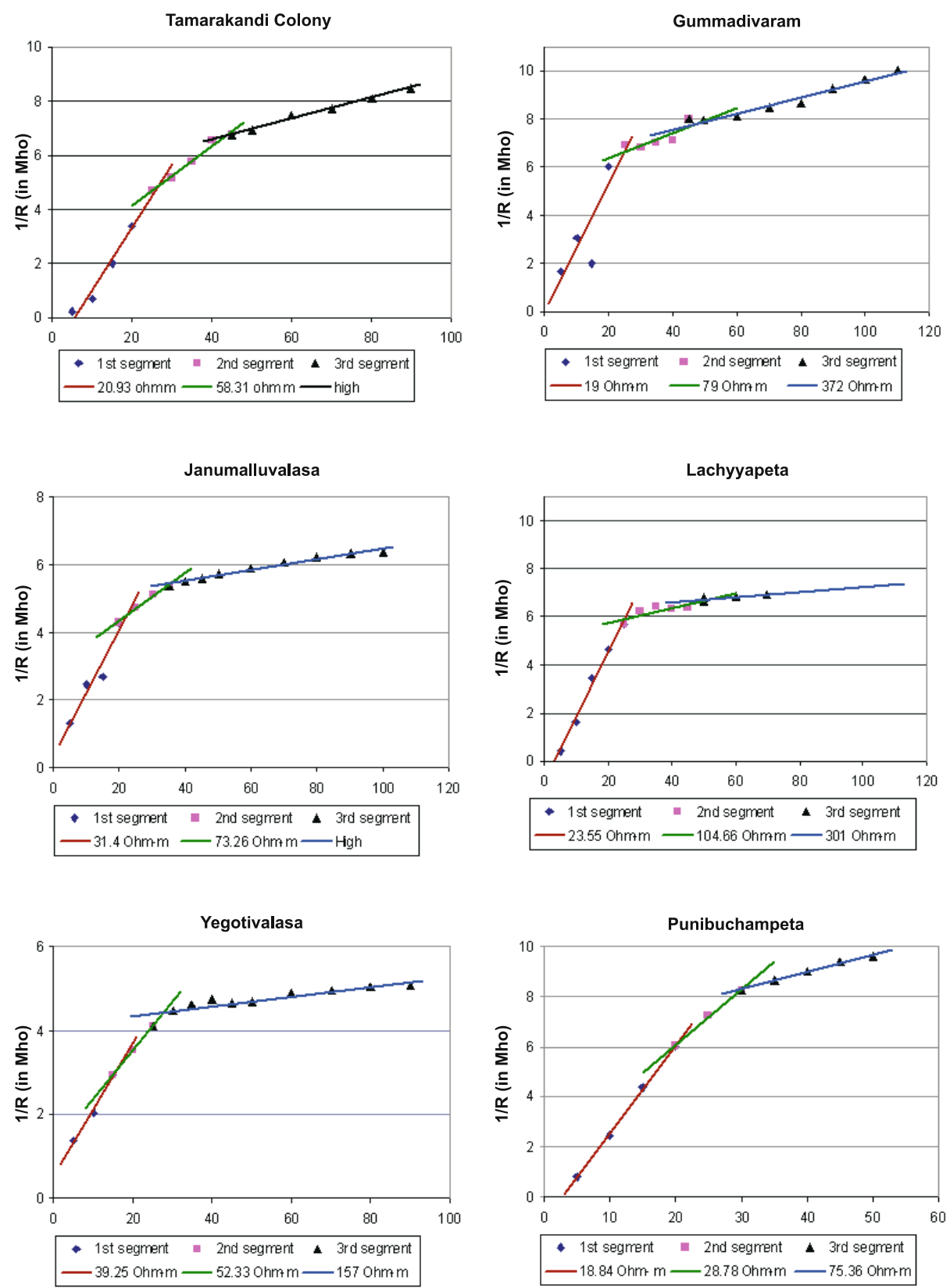

Figure 3. Plots of reciprocal resistance versus electrode separation, Seethanagaram Mandal.

between the water saturated weathered rock and the unsaturated hard rock. Thus, 50 vertical electrical soundings were carried out in 2005 using Wenner electrode configuration with the help of SSR-MPL instrument fabricated by IGIS, Hyderabad. Totally 5 VESs were carried out individually in and around each village. Considering the variation in the apparent resistivity for each electrode separation, while keeping the place of observation constant, quantitative interpretation of the electrical resistivity data was undertaken using the inverse slope method. Six VES curves are shown in figure 3. Based on the resistivity data, 20 sites were recommended for drilling. The depths to the basement values computed from VES, were in good agreement with the actual figures obtained from the lithologic data of bore wells. This interpretation helped us to understand the subsurface layering, and depth to basement. But 10 out of 20 locations have given a good indication of water bearing zones (table 1). A comparison of resistivity results of table 1 with lithologs of bore wells and cross section of open well indicates that the resistivity of top layer varies from 12.0 to $42.0 \Omega \mathrm{m}$. The subsequent layers are weathered and massive granite. A perusal of table 1 shows that the ranges of resistivitiy values of the subsurface strata are as below: 
Table 1. Results of geoelectrical layers at drilling sites.

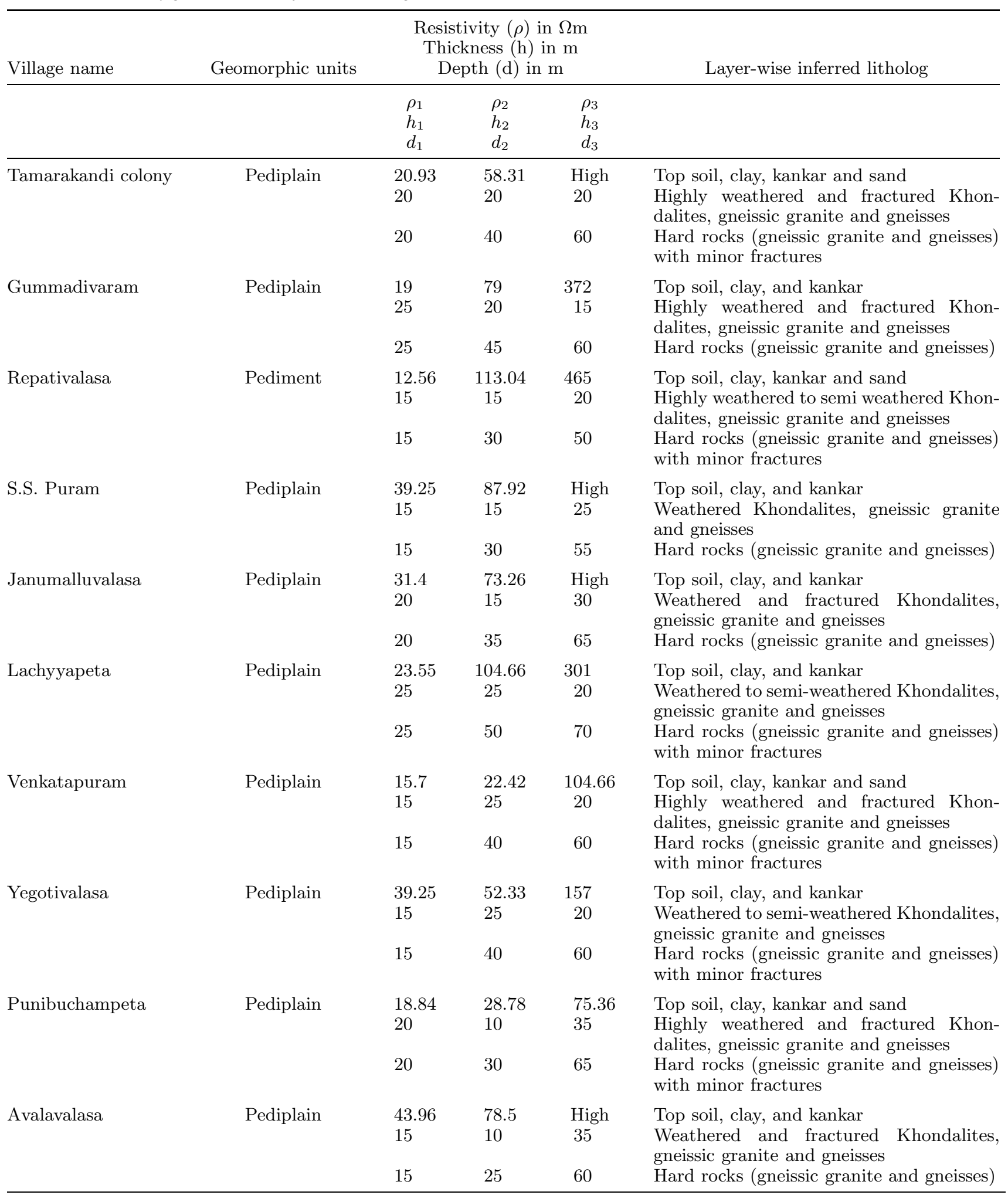

$<40 \Omega \mathrm{m} \quad$ : Top soil/sand and clay

$40-80 \Omega \mathrm{m} \quad$ : Weathered granite and gneissic granite

80-170 $\Omega \mathrm{m}$ : Semi-weathered granite and gneissic granite
130-300 $\Omega \mathrm{m}$ : Morrum and kankar

170-400 $\Omega \mathrm{m}$ : Minor fracture and unweathered gneissic granite and gneisses

$>400 \Omega \mathrm{m} \quad$ : Hard rock (gneissic granite and gneisses) 


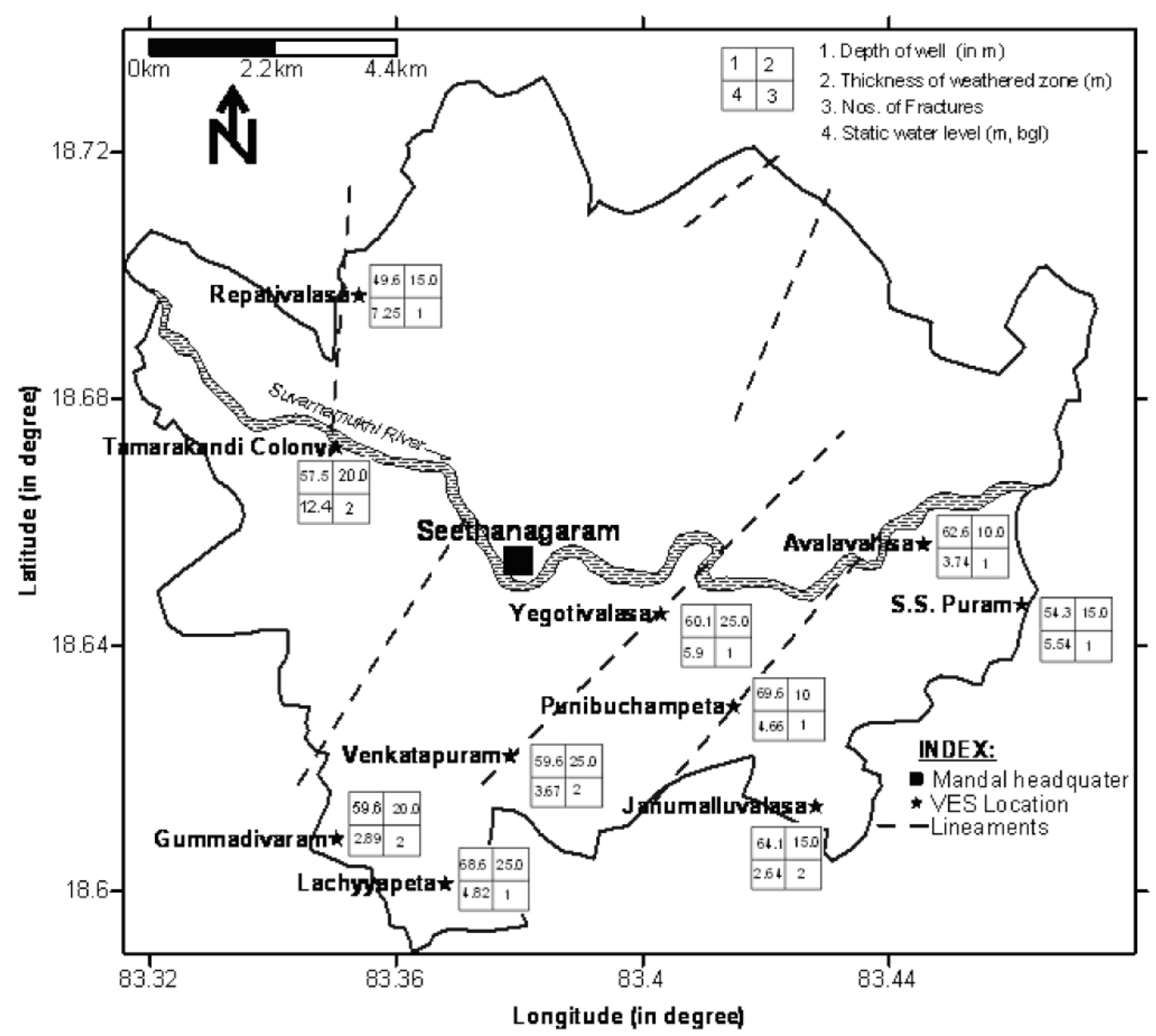

Figure 4. Location of VES and drilling sites showing depth of well and water table, thickness of weathered zones and number of fractures.

Figure 4 presents the depth of bore wells, thickness of weathered zone, depth to water level and number of existing fractures. It implies that the thickness of weathered zones varies from 10 to $25 \mathrm{~m}$ and at least 1-2 fractures exist in the weathered zones at the 10 drilling sites.

\section{Step draw down pumping test}

A step draw down test helps in computation of well efficiency, well productivity and also in determining the safe discharge rate for any well for selection of a suitable pump set. The draw down at a well includes not only that of the logarithmic draw down curve at the well face, but also a well loss caused by flow through the well screen and flow inside of the well to the pump intake. Because the well loss is associated with turbulent flow, it may be indicated as being proportional to $n$th power of the discharge as $Q^{n}$, where $(n)$ is a constant greater than one. The draw down $(S)$ in a well pumped with a discharge rate $(Q)$ is given by the sum of the draw down $(B Q)$ of the aquifer at the well, and the draw down $\left(C Q^{n}\right)$ due to the movement of water into the well through the developed zone or gravel envelope and screen or slot in the casing. The relation of draw down is given by

$$
S=B Q+C Q^{n}
$$

where $B=$ coefficient of aquifer loss and $C=$ coefficient of well loss.

Jacob (1947) suggested that a value $n=2$ might be reasonably assumed, but Rorabaugh (1953) pointed out that $n$ can deviate significantly from 2 . An exact value for $(n)$ cannot be stated because of differences of individual wells. The detailed investigations of flow inside and outside of wells show that the considerable variations occur from assumed flow distributions. The time draw down data obtained from the step draw down test help in the determination of the coefficient values of $B$ and $C$.

The time draw down and time recovery data for different steps were plotted on a semi-log graph. The time required for achieving complete recovery 

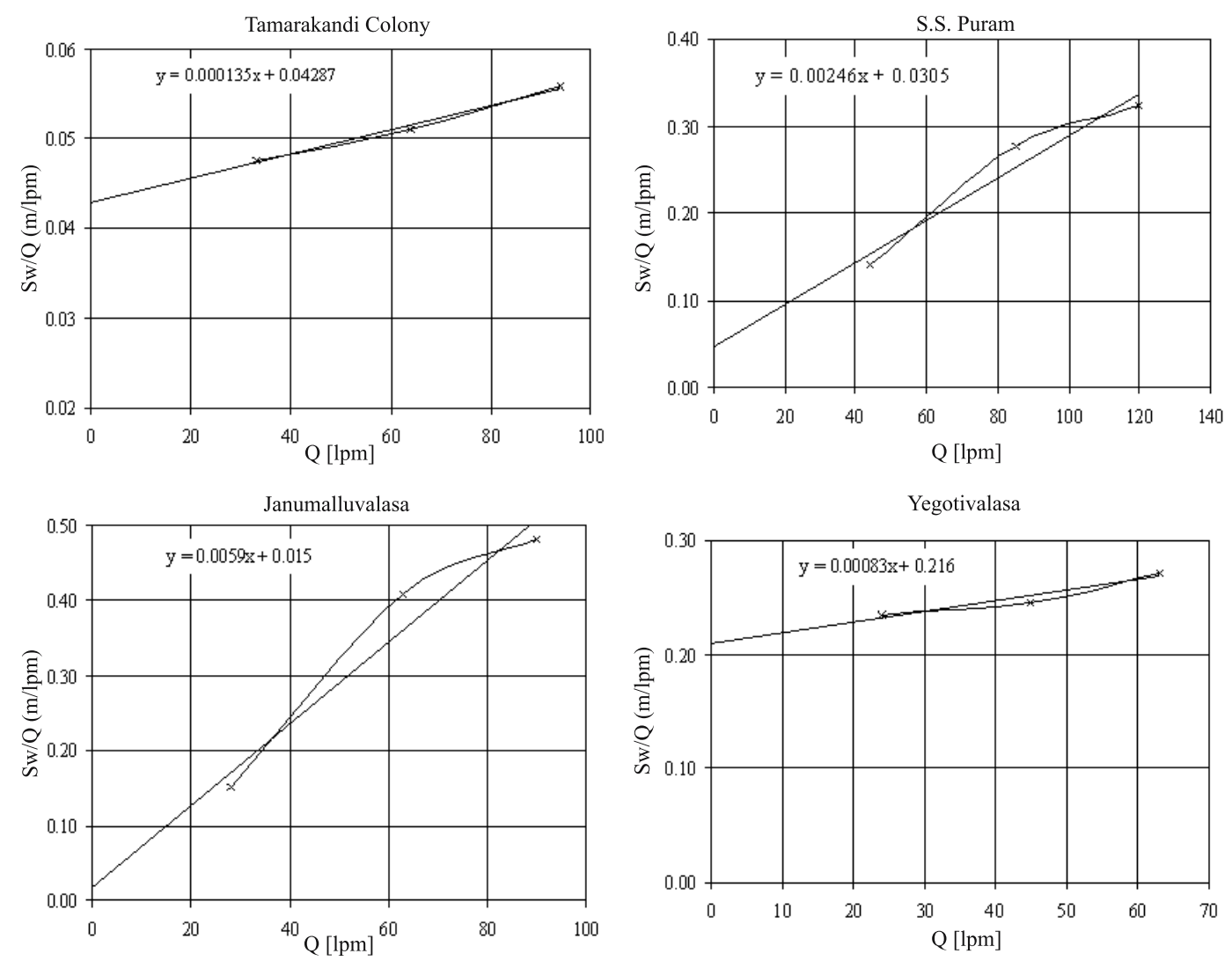

Figure 5. Cross plots of $\left(S_{w} / Q\right)$ vs. $Q$ for determination of $B$ and $C$.

(SWL) is estimated by proper extrapolation of the recovery curve. The recovery period thus estimated is subtracted from 24 hours, which gives the optimum time period for pumping the well. The time draw down curves is extrapolated to this time and the draw down is noted for each step. The ratio of draw down $\left(S_{1}\right)$ and the corresponding discharge rate $\left(Q_{1}\right)$ are calculated. Values of $\left(S_{1} / Q_{1}\right)$ are plotted against $Q_{1}$, and the least square straight line is fitted through the points (as shown in figure 5). The intercept and slope give the coefficient of the aquifer losses, $B$ and well losses, $C$, respectively by trial and error.

\subsection{Specific capacity and well efficiency}

Specific capacity $\left(Q / S_{w}\right)$ of a well is the discharge per unit draw down in the well and is usually expressed in $\mathrm{lpm} / \mathrm{m}$. This is a measure of well efficiency. The specific capacity of a well is not constant but decreases with the increase in pumping rate $(Q)$ and prolonged pumping $(t)$. If the well is small in diameter and is pumped at a higher rate, the frictional losses will increase. The maximum safe yield (recommended yield) of a well is the capacity of the aquifer to supply water without causing a continuous lowering of the water table and is therefore, limited by the rate at which the ground water is replenished by the recharge. Excessive lowering of the ground water table by pumping may affect the surrounding water sources.

The efficiency of the well for a particular discharge is calculated by

$$
\frac{B Q}{S_{w}}
$$

where, $B=$ coefficient of aquifer or formation loss, $Q=$ discharge and $S_{w}=$ specific draw down.

The efficiency of 10 bore wells are calculated by well loss divided by the draw down, $B Q / S_{w}$ (presented in table 2). This result also provides the specific capacity of the well which is a measure of productivity.

\section{Discussions and conclusions}

Figure 4 presents locations and results of investigation of 10 favourable sites. Tamarakandi colony of Seeethangaram Mandal is one of 10 sites on a major lineament and on the bank of the Suvarnamukhi river. The interpreted geoelectrical section matches well with the borehole litholog. The VES carried out at Tamarakandi colony reveals a $20 \mathrm{~m}$ top layer of clay, kankar and sand zone with resistivity of $20.93 \Omega \mathrm{m}$. It shows weathered and highly 


\begin{tabular}{|c|c|c|c|c|c|c|c|c|c|}
\hline 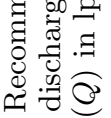 & $\S$ & ষ্ণి & 兽 & 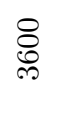 & $\begin{array}{l}8 \\
\stackrel{2}{\stackrel{N}{N}}\end{array}$ & $\underset{\text { \} }{\stackrel{N}{N}}} &{\text { 吕 }} &{\text { 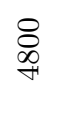 }} &{\text { 总 }} \\
{\hline} &{\begin{array}{l}\infty \\
\stackrel{2}{N} \\
\stackrel{N}{N}\end{array}} &{\text { is }} &{\underset{\infty}{\stackrel{10}{\infty}}} &{\infty} &{8} &{\text { 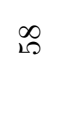 }} &{\stackrel{\mathscr{\vartheta}}{\varrho}} &{\mathscr{\infty}} &{1} \\
{\hline \text { 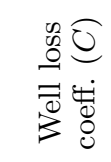 }} &{\begin{array}{l}\stackrel{20}{9} \\
\stackrel{9}{9} \\
\stackrel{0}{0} \\
\stackrel{0}{0}\end{array}} &{\text { 今a }} &{\text { 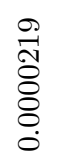 }} &{\text { 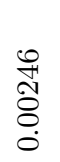 }} &{\begin{array}{l}\stackrel{8}{8} \\
\stackrel{8}{8} \\
\stackrel{0}{0}\end{array}} &{\begin{array}{l}\stackrel{2}{8} \\
\stackrel{8}{8} \\
0\end{array}} &{\begin{array}{l}\vec{\sigma} \\
\vdots \\
0\end{array}} &{\begin{array}{l}\dddot{0} \\
\ddot{0} \\
8 \\
0 \\
0\end{array}} &{1} \\
{\hline \text { 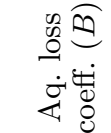 }} &{\text { 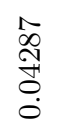 }} &{\stackrel{\text { ô }}{\circ}} &{\begin{array}{l}20 \\
\overrightarrow{7} \\
0 \\
0\end{array}} &{\begin{array}{l}\qquad 8 \\
\stackrel{0}{0} \\
\stackrel{0}{0}\end{array}} &{\begin{array}{l}20 \\
\ddot{0} \\
0\end{array}} &{\begin{array}{l}\stackrel{10}{\circ} \\
\stackrel{0}{0} \\
0\end{array}} &{\text { 等 }} &{\begin{array}{l}0 \\
\stackrel{N}{0} \\
0\end{array}} &{1} \\
$\hline
\end{tabular}

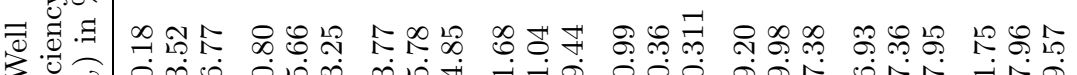

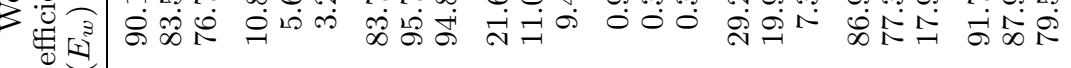

总:

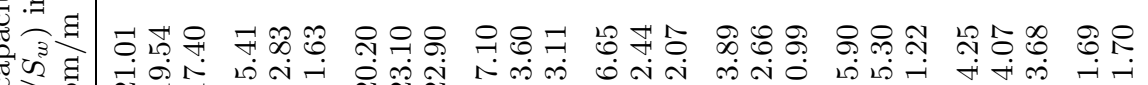
व

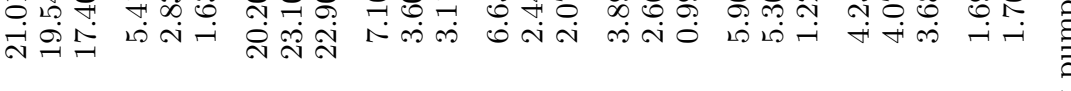

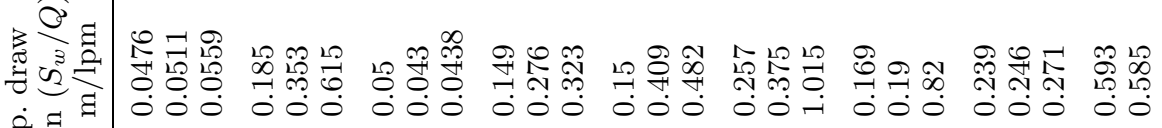

¿

-

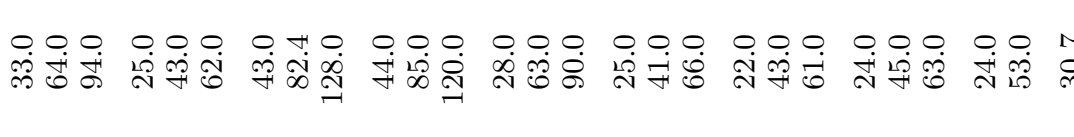
尊. 


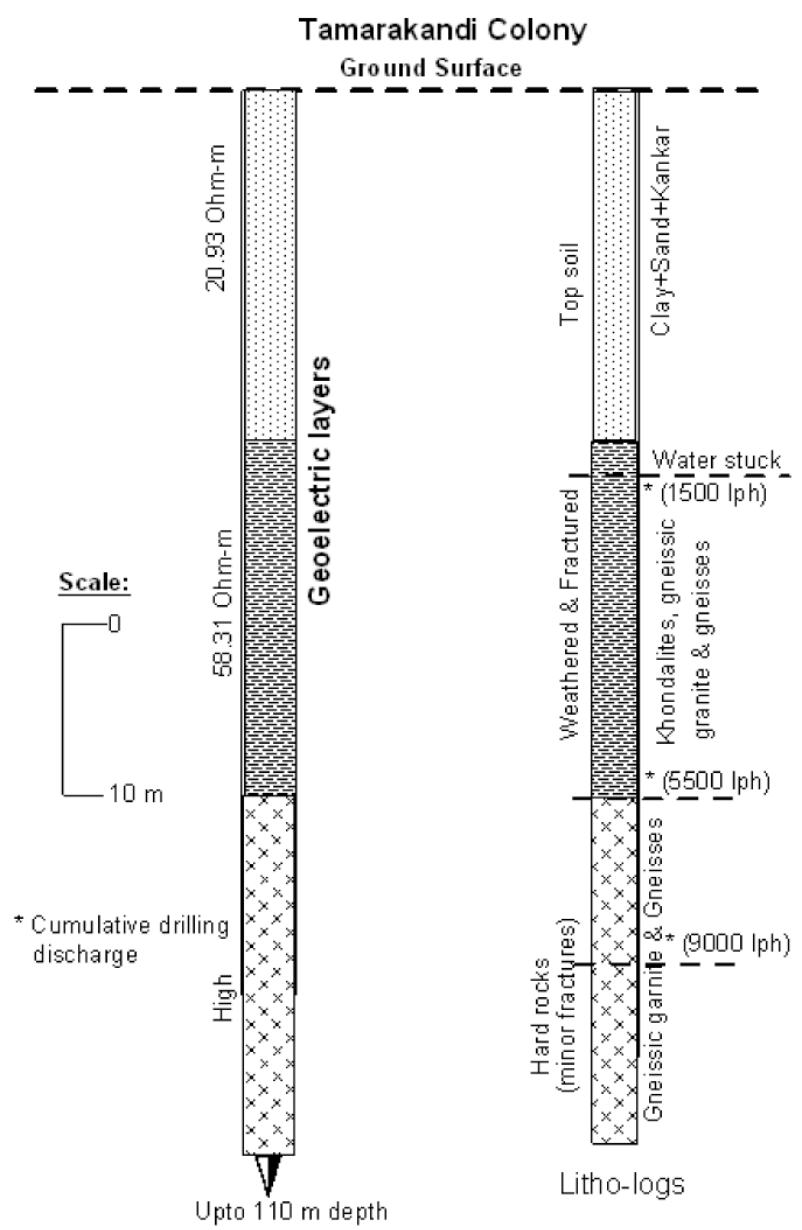

Figure 6. Comparison of geoelectrical layers and lithologs at Tamarakandi Colony.

fractured zones having resistivity of $58.31 \Omega \mathrm{m}$ and that of massive gneissic granite and gneisses with minor fractures and high resistivity at a depth below $45 \mathrm{~m}$ (figure 6 ). The water saturated zone was first encountered at $23.0 \mathrm{~m}$ depth in the highly weathered and fractured khondalites, gneissic granite and gneisses with an initial yield of $1500 \mathrm{lph}$. The main aquifer occurs at a depth of $40 \mathrm{~m}$, which extends down to $50 \mathrm{~m}$ depth recording drilling discharge of 5500 to $9000 \mathrm{lph}$. The yield of this bore well was also confirmed by conducting the step draw down pumping test which showed optimum yield of 15,480 lph and recommended a yield of 9000 lph (table 2).

Gummadivaram village was chosen for its close location to a small tank, and belongs to the pediplain. The VES result shows that the top layer is completely clay and sand bearing $19.0 \Omega \mathrm{m}$ resistivity. The water was struck at $3 \mathrm{~m}$ depth in clay and sand zone with initial yield of $500 \mathrm{lph}$. The main aquifer was met at $22.50 \mathrm{~m}$ depth in the gravel and pebble zones extending down to $40 \mathrm{~m}$ depth producing the yield of 1500-3000 lph. The interpreted geoelectrical section matches well with the

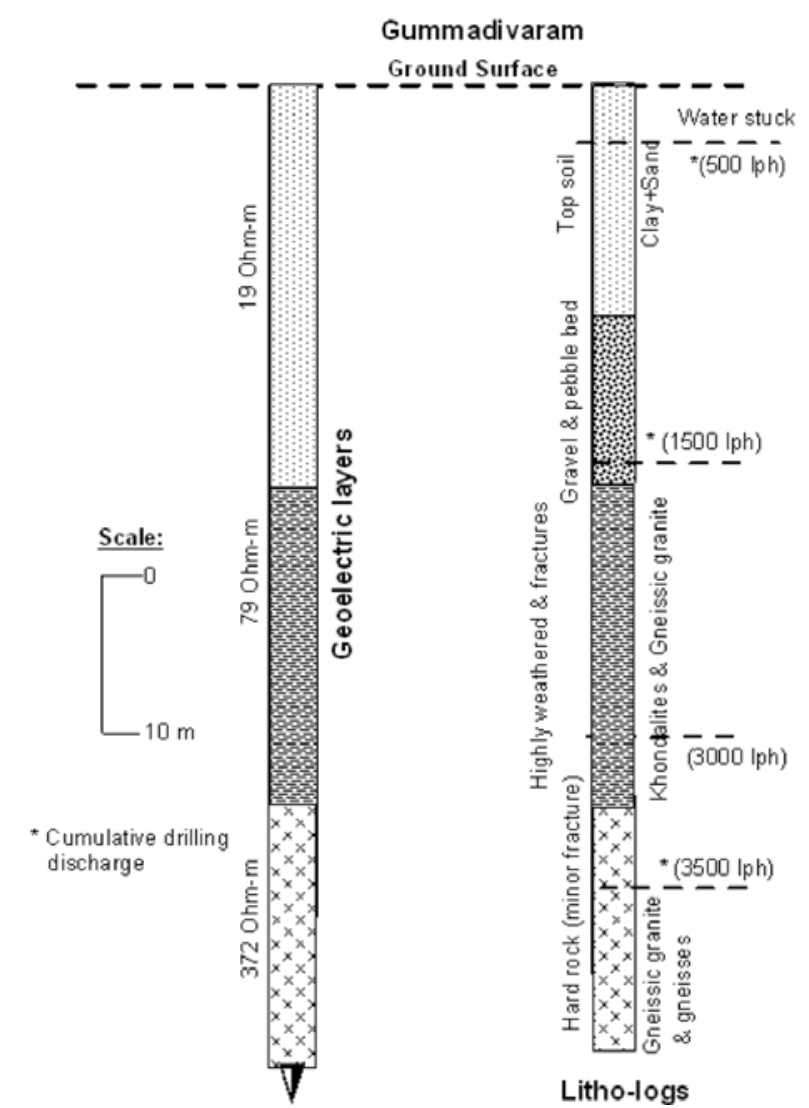

Figure 7. Comparison of geoelectrical layers and lithologs at Gummadivaram.

observed lithology (figure 7) indicating the resistivities of weathered zone as $79 \Omega \mathrm{m}$, and of the massive gneissic granite and gneisses as $372 \Omega \mathrm{m}$. At $50 \mathrm{~m}$ depth in hard rock, one fracture zone was encountered with a yielding capacity of $3500 \mathrm{lph}$. The yield of this bore well was confirmed by conducting the step draw down test which showed optimum yield of $3540 \mathrm{lph}$, and the recommended yield was computed as $2000 \mathrm{lph}$.

The VES site at Janumalluvalasa village falls on a tank as inferred from the drainage map and located on the pediplain. Here, VES result presents three geoelectrical layers (figure 3). The drilling results show that water was struck at $18.0 \mathrm{~m}$ depth with an initial yield of $2000 \mathrm{lph}$. The main aquifer occurs at $25 \mathrm{~m}$ depth, and extends down to a depth of $38 \mathrm{~m}$ yielding 3500 to $4500 \mathrm{lph}$. The interpreted geoelectrical section correlates well with the borehole litholog (figure 8), showing the coarse sand and pebble zones with resistivity of $31.4 \Omega \mathrm{m}$; highly weathered and fractured khondalites, gneissic granite and gneisses with resistivity of $73.26 \Omega \mathrm{m}$, and massive gneissic granite and gneisses with high resistivity values. The yield of this bore well was also confirmed by conducting the step draw down test. This test indicates optimum yield of 4, $140 \mathrm{lph}$ and the recommended yield was computed as 


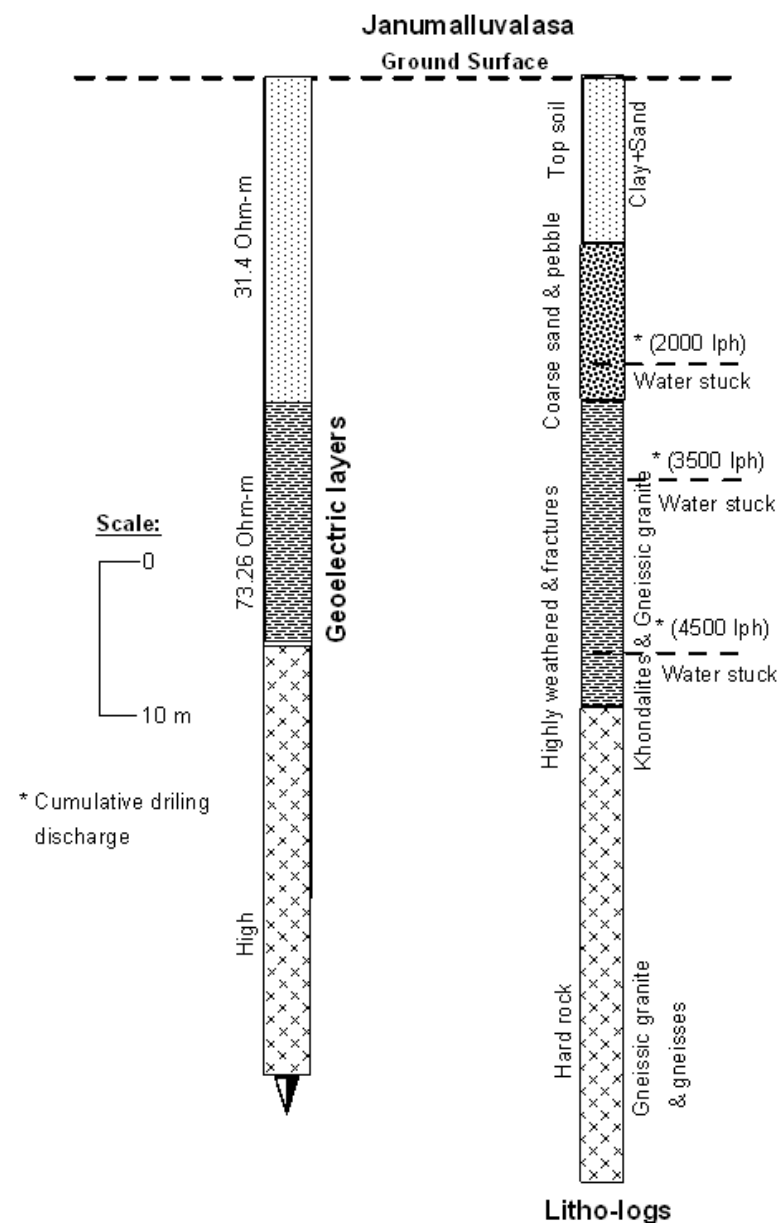

Figure 8. Comparison of geoelectrical layers and lithologs at Janumalluvalasa.

$2500 \mathrm{lph}$ and similar matching was obtained at the other 7 sites of this study area too. The maximum optimum yield was 22,500 lph (375 lpm) at Repativalasa village (falls under pediment) where the recommended discharge was $5000 \mathrm{lph}$. The optimum yield and recommended discharge of 10 drilled bore wells vary from 3480 to $22,500 \mathrm{lph}$ and 900 to 9000 lph respectively.

In general, the hard rock formations do not have good groundwater potential. Still, integrated studies help to ascertain the presence of hidden waterbearing formations. Resistivity sounding proved to be an effective tool to locate the productive zones, when interpreted in conjunction with hydrogeological and hydrogeomorphic data. Of course, all the relevant and situation-specific features would have to be taken into consideration while deciding the overall approach for groundwater exploration strategy.

\section{Acknowledgements}

The authors wish to thank to Dr. V P Dimri, Director, NGRI, Hyderabad for his kind support and permission to publish this paper. The authors are grateful to VISHWAS for allowing utilization of the data and the anonymous reviewers for their valuable suggestions to improve the manuscript.

\section{References}

Barker R, Rao T V and Thangarajan M 2001 Delineation of contaminant zone through electrical imaging technique; Curr. Sci. 81(3) 277-283.

Compagnie General de Geophysique 1963 Master curves for electrical soundings; 2nd edn; European Association of exploration Geophysicists, The Hague, pp. 49.

Ghosh D P 1971 Inverse filter coefficients for computation of apparent resistivity standard curves for a horizontally stratified earth; Geophysical Prospecting $\mathbf{1 9}$ 769-775.

Hummel J N 1931 A theoretical study of apparent resistivity in surface potential methods; AIME Tech. Publn. No. 418.

Jacob C E 1947 Draw down test to determine effective radius of artesian well; Trans. Amer. Soc. of Civil Engrs. 112, paper 2321, 1047-1064.

Mabee S B, Curry P J and Hardcastle K C 2002 Correlation of lineaments to ground water inflows in bedrock tunnel; Ground Water 40(1) 37-43.

Mabee S B. Hardcastle K C and Wise D U 1994 A method of collecting and analyzing lineaments for regional scale fractured-bedrock aquifer studies; Ground Water 32(4) 884-894.

Magowe M and Carr J R 1999 Relationship between lineaments and ground water occurrence in western Botswana; Ground Water 37(2) 282-286.

Mooney H M and Wetzel W W 1956 The potentials about a point electrode and apparent resistivity curves for a twothree and four layered earth; Minneapolis, University of Minnesota Press, pp. 146

Moore R W 1945 An empirical method of interpretation of earth resistivity measurements; AIME Tech. Publ. No. 1743.

Narayan P V S and Ramanujachary K R 1967 An inverse slope method determining absolute resistivity; Jr. Geophysics 32 1036-1040.

Orellana E and Mooney H M 1966 Master tables and curves of vertical electrical sounding over layered structures; Interciencia, Madrid, pp. 193.

Patra H P and Nath S K 1999 Schlumberger geoelectrical sounding in groundwater: principles, interpretation and application; A A Balkema, Rotterdam; and Oxford \& IHB Publishing Company Pvt. Ltd., New Delhi, pp. 153.

Raju K C B, Rao G V K and Kumar B J 1989 Analytical aspects of remote sensing techniques for groundwater prospecting in hard rocks; Proc. of the 6th Asian Conference on Remote Sensing, pp. 127-132.

Rangarajan R and Athavale R N 2000 Annual replenishable groundwater potential of India - an estimate based on injected tritium studies; J. Hydrol. 234 38-53.

Roman I 1934 Some interpretation of earth resistivity data; AIME Trans. 110183.

Rorabaugh M J 1953 Graphical and theoretical analysis of step-drawdown test of artesian well; Proc. Amer. Soc. Civil Engrs., vol. 79, separate no. 362, 23 pp.

Sander P, Minor T M and Chesley M M 1997 Groundwater Exploration based on lineament analysis and reproductivity tests; Ground Water 35(5) 888-894. 
State Ground Water Department (SGWB) 2005 District report, Vizianagaram; p.87.

Tagg G F 1934 Interpretation of resistivity measurements; AIME. Trans. 110135.

Van Dam J C 1967 Mathematical denotation of standardgraphs for resistivity prospecting in view of their calculation by means of a digital computer; Geophysical Prospecting $\mathbf{1 5}$ pp. 57-70.

Yin Z Y and Brook G A 1992 The topographic approach to locating high yield wells in crystalline rocks: Does it work?; Ground Water $\mathbf{3 0}(\mathbf{1})$ 96-101.

MS received 3 August 2007; revised 3 December 2007; accepted 13 December 2007 